\title{
PROBLEMS OF CONTEMPORARY CLIMATOLOGY IN THE DOMAIN OF CLIMATE CHANGE
}

The progressing warming of the Earth's climate (of both hemispheres) during the last two centuries brought about the alarming opinions on the negative consequences of human activity. This global warming is usually attributed to the systematic increase of carbon dioxide $\left(\mathrm{CO}_{2}\right)$ content in the atmosphere and the resulting greenhouse effect.

\section{NATURAL OR ANTHROPOGENIC GLOBAL WARMING?}

The secular changes of air temperature in the moderate zone, considered here, have been determined on the basis of the longest chronological time series recorded in eight places located in Central and Western Europe. The length of the measurement series attains more than 300 years for Middle England (16591973), more than 200 years for Geneva (1768-1980), Warsaw (1779-1990) and Prague (1771-1980), and more than 100 years for Cracow (1826-1990), Wrocław (1851-1980), Zurich (1864-1980) and Potsdam (1893-1992).

The secular trends displayed by air temperature in these localities, represented by the linear regression equations $T=A_{0}+A t$ (with regression coefficients $A$ expressed in ${ }^{\circ} \mathrm{C} / 100$ years) are as a rule upward trends, and it is especially winters that are getting increasingly warmer: in Warsaw by $1.03^{\circ} \mathrm{C} / 100$ years, in Cracow by $1.38^{\circ} \mathrm{C} / 100$ years, in Wrocław by $0.12^{\circ} \mathrm{C} / 100$ years, in Prague by $0.25^{\circ} \mathrm{C} / 100$ years, in Zurich by $0.64^{\circ} \mathrm{C} / 100$ years, in Geneva by $0.51^{\circ} \mathrm{C} / 100$ years, in Potsdam by $0.10^{\circ} \mathrm{C} / 100$ years, and in Middle England by $0.32^{\circ} \mathrm{C} / 100$ years.

The situation is different for the summer. The secular tendencies of air temperature in the summer season are in some localities increasing, while in other ones they are decreasing.

Thus, summers are getting warmer in Warsaw - by $0.13^{\circ} \mathrm{C} / 100$ years, in Cracow - by $0.32^{\circ} \mathrm{C} / 100$ years, and in Potsdam - by $0.92^{\circ} \mathrm{C} / 100$ years, while they are getting cooler in: Wrocław - by $0.70^{\circ} \mathrm{C} / 100$ years, Prague - by $0.25^{\circ} \mathrm{C} / 100$ years, Zurich - by $0.90^{\circ} \mathrm{C} / 100$ years, and Geneva - by $0.90^{\circ} \mathrm{C} / 100$ years, and do not change in terms of temperature in Middle England $(A=0)$. 
The annual average temperature increases in Warsaw by $0.66^{\circ} \mathrm{C} / 100$ years, in Cracow by $0.93^{\circ} \mathrm{C} / 100$ years, in Potsdam by $0.66^{\circ} \mathrm{C} / 100$ years, and in Middle England by $0.18^{\circ} \mathrm{C} / 100$ years. In the remaining localities the regression coefficients $\mathrm{A}$ are close to zero, statistically insignificant.

\begin{tabular}{|c|c|c|c|c|c|c|c|c|}
\hline $\begin{array}{c}\text { Months- } \\
\text { Seasons }\end{array}$ & Warsaw & Cracow & Wroclaw & Prague & Zurich & Geneva & Potsdam & $\begin{array}{c}\text { Middle } \\
\text { England }\end{array}$ \\
\hline I & 1.15 & 1.72 & -0.61 & 0.44 & 0.84 & 0.74 & 0.38 & 0.38 \\
II & 0.50 & 1.14 & -0.07 & 0.05 & 0.25 & 0.29 & -0.38 & 0.27 \\
III & 1.01 & 1.45 & 0.61 & 0.50 & 0.87 & 0.37 & 0.35 & 0.30 \\
IV & 0.79 & 0.85 & 0.35 & -0.01 & -0.77 & -0.20 & 0.40 & 0.22 \\
V & 0.43 & 0.69 & 0.13 & -0.44 & -.057 & -0.53 & 0.66 & 0.11 \\
VI & 0.26 & 0.07 & -0.51 & -0.09 & -1.00 & -0.23 & 0.63 & 0.00 \\
VII & 0.19 & 0.34 & -0.73 & -0.16 & -1.08 & -0.08 & 0.64 & 0.03 \\
VIII & -0.04 & 0.46 & -0.74 & -0.40 & -0.47 & -0.24 & 1.40 & -0.02 \\
IX & 0.18 & 0.43 & -0.55 & -0.41 & -0.11 & 0.08 & 1.03 & 0.12 \\
X & 0.58 & 0.32 & -0.72 & -0.25 & 0.70 & 0.00 & 1.00 & 0.24 \\
XI & 1.11 & 1.64 & 1.44 & 0.40 & 0.60 & 0.32 & 1.25 & 0.20 \\
XII & 1.36 & 1.96 & 1.00 & 0.26 & 1.05 & 0.47 & 0.62 & 0.32 \\
XII-II & 1.03 & 1.38 & 0.12 & 0.25 & 0.64 & 0.51 & 0.10 & 0.32 \\
III-V & 0.79 & 0.99 & 0.37 & 0.00 & -0.15 & -0.12 & 0.50 & 0.21 \\
VI-VIII & 0.13 & 0.32 & -0.70 & -0.25 & -0.90 & -0.19 & 0.92 & 0.01 \\
IX-XI & 0.66 & 0.81 & 0.05 & -0.11 & 0.38 & 0.14 & 1.11 & 0.19 \\
X-III & 1.00 & 1.37 & 0.29 & 0.22 & 0.65 & 0.37 & 0.53 & 0.29 \\
IV-IX & 0.31 & 0.48 & -0.37 & -0.27 & -0.70 & -0.20 & 0.81 & 0.08 \\
I-XII & 0.66 & 0.93 & -0.04 & -0.03 & 0.03 & 0.08 & 0.66 & 0.18 \\
\hline monthly & 0.64 & 0.95 & 0.00 & 0.00 & 0.06 & 0.09 & 0.72 & 0.18 \\
averages & & & & & & & & \\
\hline 12- & 0.64 & 0.93 & -0.02 & -0.01 & 0.01 & 0.09 & 0.64 & 0.19 \\
month & & & & & & & & \\
\hline & & & & & & & & \\
\hline
\end{tabular}

The climate of Warsaw has been warming up in the period 1779-1990 on the average by $0.66^{\circ} \mathrm{C} / 100$ years in accordance with the following regression equation:

$T=6.915+0.006572 \mathrm{t}, \quad r=0.57$

This warming may to a large extent result from the increased activity of the Sun (Wolf numbers, Fig. 1) and the decreased volcanic activity $I=D V I / \Delta t(D V I-$ dust veil index of $\mathrm{H}$. Lamb), i.e. the increasing time intervals between consecutive eruptions:

$\mathrm{W}=20.80+0.1683 \mathrm{t}, \quad r=0.31$, $\mathrm{I}=258.3-0.49066 t, \quad r=-0.57$, $\Delta t=1.72+0.019 t, \quad r=0.22$.

Solar activity has been increasing in the years 1779-1993 on the aver- 
age by 16.8 per 100 years, i.e. from 24.2 to 57.1 (by more than $50 \%$ with respect to the average of $w^{*}=50$ ).

Along with the increase of solar activity the solar constant increases as well, and the dependence of the latter on the Wolf numbers is defined through the formula of K. Kondratev and G. Nikolskii (1970): $S=1.903+0.011 \mathrm{~W}^{0.5}-0.0006 \mathrm{~W}$.

The value of the solar constant attains its maximum value $S_{\max }$ for the Wolf number $W=84$.
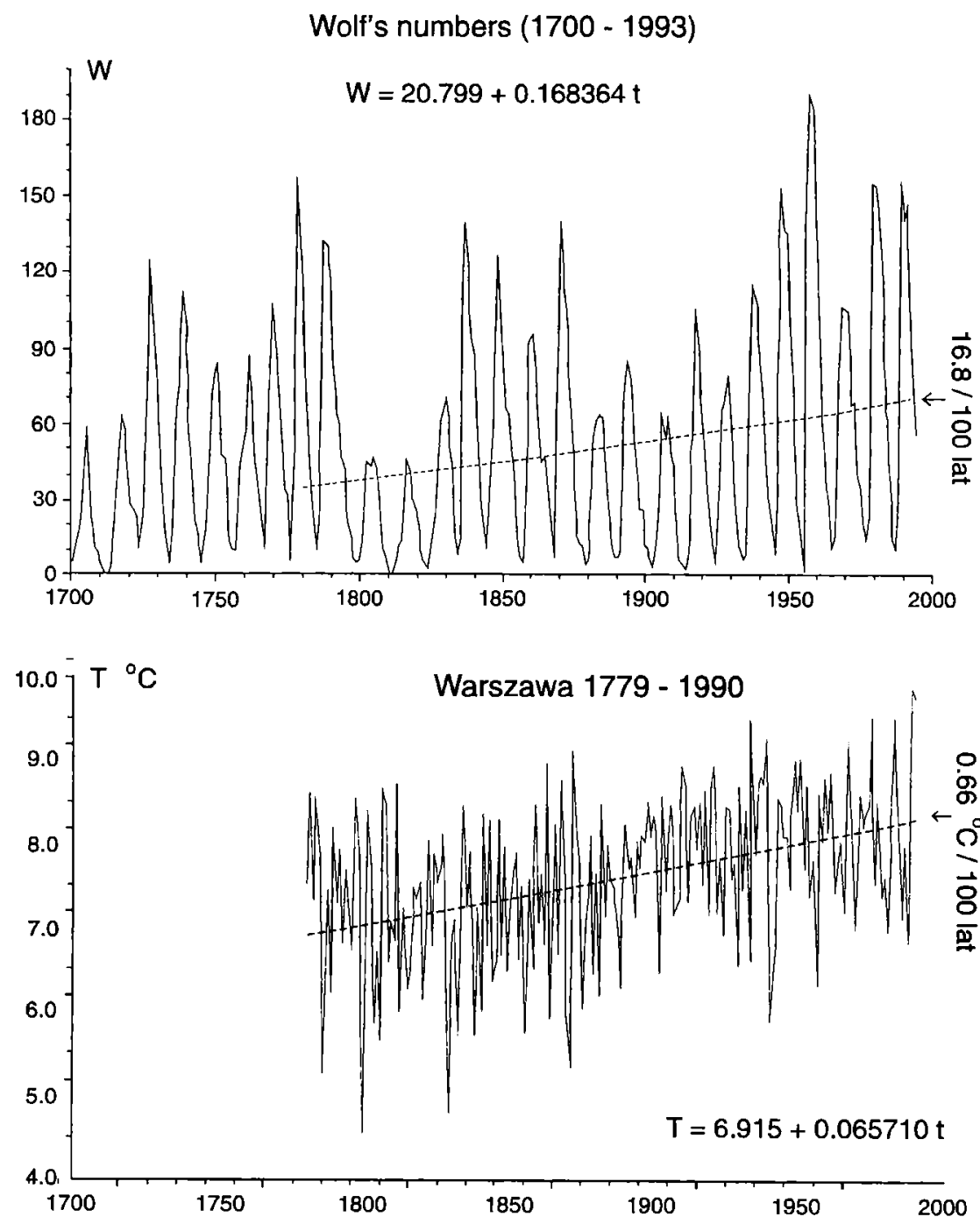

Fig. 1. Increasing trends of solar activity (of the Wolf numbers - by $16.8 / 100$ years) and of air temperature in Warsaw (by $0.66^{\circ} \mathrm{C} / 100$ years) in the years $1779-1993$. 
In the years 1700-1993 the solar constant changed in the 11-year cycle by $2.5 \%$ (see Fig. 2 for the approximation with the polynomial of 10 th order). Its secular fluctuations are roughly equal $1 \%$ (with respect to annual averages), and the change trend is increasing.

The actual increasing trend of the solar constant is most probably even bigger, insofar as a decrease is observed of the volcanic activity, $I=D V I / \Delta t$ - in the years $1680-1980$ by 49 DVI per annum per 100 years, and the less

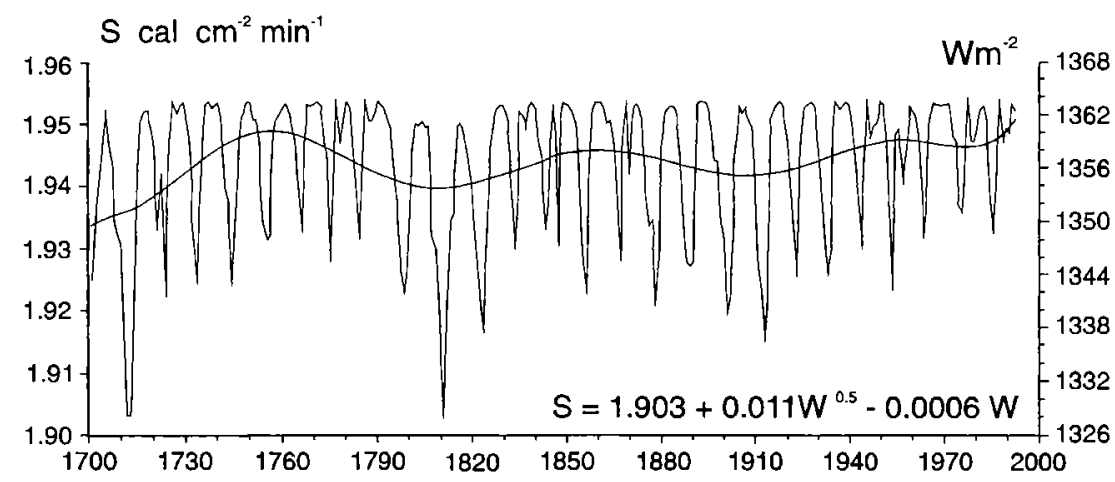

Fig. 2. Increasing trend of the solar constant (s) in the years 1700-1993 (values calculated from the Kondratev-Nikolskii, 1970, formula).

and less frequent volcanic eruptions (the time interval $\Delta t$ gets longer and longer, see Fig. 3). It is known that the fine volcanic dust can remain in the stratosphere even for a dozen years. It disperses solar radiation in all directions, thereby decreasing the solar constant.

The secular trends, increasing or decreasing, of the air temperature in the localities here quoted do not support - and even partly negate - the hypothesis that the global climate warming results from the greenhouse effect, caused by the increase of $\mathrm{CO}_{2}$ contents in the atmosphere. The hypothesis mentioned is contradicted by the annual cycle and the differentiation of the secular trends $(A)$ of air temperature. Thus, for instance, the warm half-years (IV-IX) are increasingly warm: in Warsaw by $0.31^{\circ} \mathrm{C} / 100$ years, in Cracow - by $0.48^{\circ} \mathrm{C} / 100$ years, in Potsdam - by $0.81^{\circ} \mathrm{C} / 100$ years, in Middle England - by $0.08^{\circ} \mathrm{C} / 100$ years (the last coefficient is statistically insignificant). This season, though, is getting cooler in: Wrocław by $0.37^{\circ} \mathrm{C} / 100$ years, in Prague - by $0.27^{\circ} \mathrm{C} / 100$ years, in Zurich - by $0.70^{\circ} \mathrm{C} / 100$ years, and in Geneva - by $0.20^{\circ} \mathrm{C} / 100$ years.

A similar situation is observed in other latitudes - in the polar zone (Spitsbergen, 1912-1985), as well as in the equatorial zone (Colombo, 18691980). In Colombo, progressing cooling is observed for the majority of cases, especially in spring - by $0.25^{\circ} \mathrm{C} / 100$ years, and in autumn - by $0.17^{\circ} \mathrm{C} / 100$ years. The annual average air temperature is virtually not changing (the respective $A=-0.09^{\circ} \mathrm{C} / 100$ years). 
In spite of the short time series of measurements for Spitsbergen (97 years) the regression coefficient $A$ changes its sign during the year - between $5.88^{\circ} \mathrm{C} / 100$ years (in winter) and $-1.55^{\circ} \mathrm{C} / 100$ years (in June).

Solar activity W(1700 - 1993)

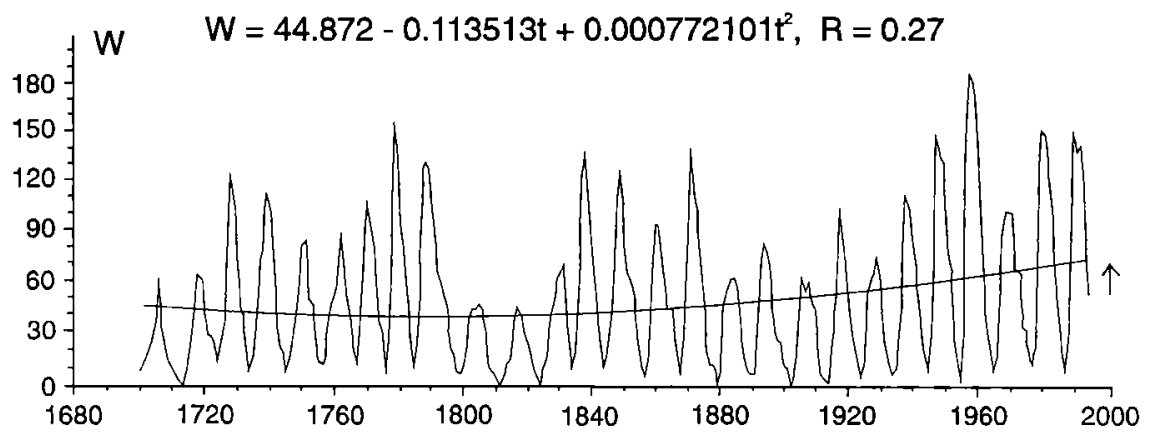

Volcanic eruption DVI (1680 - 1980)

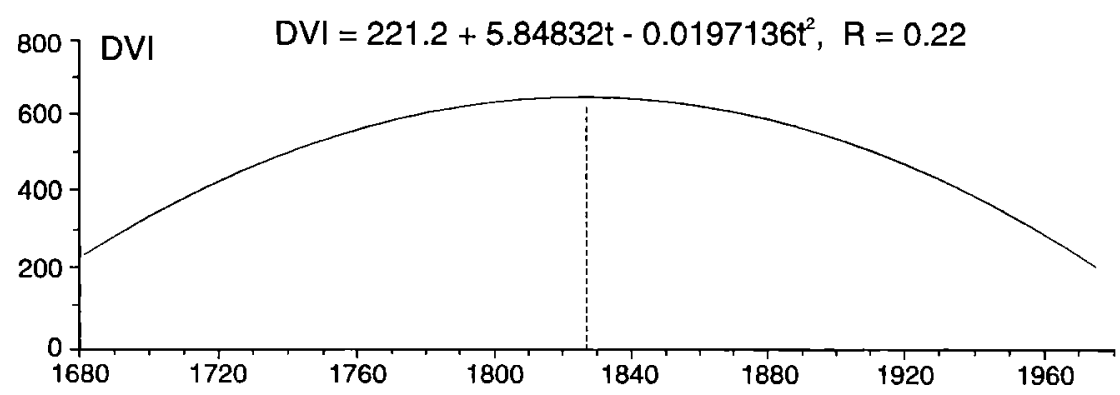

Volcanic eruption DVI (1680 - 1980)

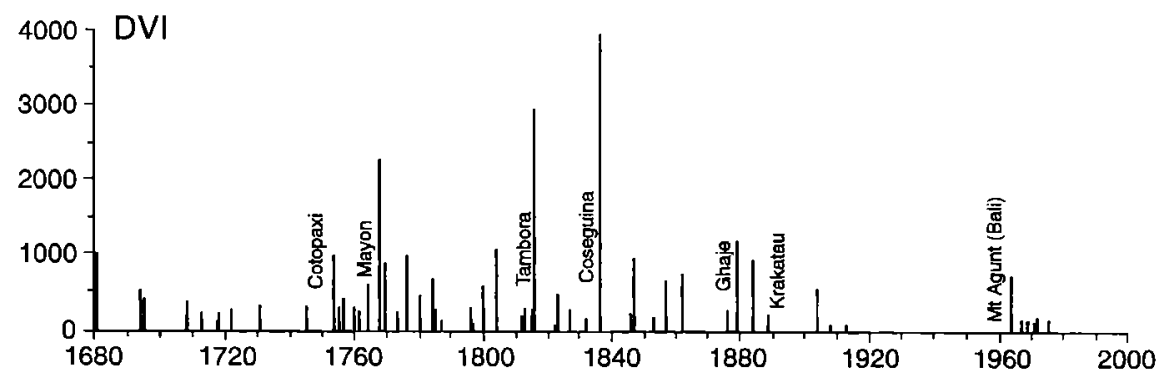

Fig. 3. Temporal changes of Wolf numbers $(W)$ and the dust veil index $(D V I)$ of $H$. Lamb; Solar activity $W$, Volcanic eruptions $D V I$, Volcanic eruptions. 
The quite high positive values of the regression coefficient $A$ in winter can be caused by the local factors - "urban heat islands". They can result from the increasing accumulation of heat by the overbuilt areas (artificial surfaces featuring low albedo, particularly in winter).

Along with this, the raising of the ocean and sea levels is observed. The level of the Baltic Sea (in Świnoujście, 1811-1990, see Kozuchowski, Boryczka, 1997) increases on the average by $0.49 \mathrm{~mm} /$ year (spring $0.14 \mathrm{~mm} /$ year, summer $-0.39 \mathrm{~mm} /$ year, autumn $-0.68 \mathrm{~mm}$ /year, winter $-0.45 \mathrm{~mm} /$ year).

The global warming of the climate is being attributed to the greenhous effect cuased by the carbon dioxide $\left(\mathrm{CO}_{2}\right)$. The concentration of $\mathrm{CO}_{2}$ in the atmosphere increases more and more rapidly. According to the empirical exponential formula of H.Oeschger and U.Siegenthaler (1987) the content will reach in the middle of the next century (in 2053) the value of $600 \mathrm{ppm}$.

It is estimated that after the $\mathrm{CO}_{2}$ content in the atmosphere will have doubled (as compared to the initial level of $280 \mathrm{ppm}$ ) the warming will take place of the lower layer of the atmosphere by 0.1 to $4.0^{\circ} \mathrm{C}$, depending upon latitude (according to the scenario of emissions of $\mathrm{CO}_{2}$ elaborated by IPCC, 1990 ). In the recently elaborated $2 \times \mathrm{CO}_{2}$ scenarios (IPCC, 1995), accounting for the cooling influence of the sulphite aerosols (which disperse solar radiation) the warming forecasted is smaller by half - amounting to between $1-2^{\circ} \mathrm{C}$ in the next century.

Users of the models generating global warming forecasts $\left(2 \times \mathrm{CO}_{2}\right.$ scenarios) abstract from the natural climate changes, caused by astronomical or geological factors, or random fluctuations.

It is generally accepted in climatology - notwithstanding the theory of chaotic dynamics - that the four glaciations of the Earth, which took place during the last million years, were not a random phenomenon, but were determined by the periodical changes of the parameters of the Earth's orbit. The dates of the four minima of solar radiation (during glaciations) are the resultant of the three overlapping cycles: of the angle of inclination of the Earth's axis with respect to the ecliptic plane -40000 years, eccentricity of the orbit -90000 years, and the motion of the equinox points with respect to the perihelion -21000 years (Milankovich, 1938).

There are interesting measurements of $\mathrm{CO}_{2}$ content and palaeotemperatures (according to deuter isotope content) in the ice cores from the Vostok antarctic station (WMO, 1990). The curves of the temperature and the $\mathrm{CO}_{2}$ content changes feature definite parallelism. A global warming analogous to the current one took place some 125000 years ago during the natural (not anthropogenic) maximum of $\mathrm{CO}_{2}$ content. According to J.G. Lockwood (1984) it is possible to refer to the theory of Milankovich in order to explain the main glaciation-interglaciation cycles of the period between 10000 and 100,000 years (see the maximum of radiation 125000 years ago).

The maximum concentration of $\mathrm{CO}_{2}$ which occurred 125000 years ago resulted most probably from the increase of temperature of the oceans, the 
natural "regulator" of the $\mathrm{CO}_{2}$ content in the atmosphere. Cooler waters absorb more of $\mathrm{CO}_{2}$ than warm waters (Flohn, 1985).

The main cause of the climate changes in the past were fluctuations of the solar constant amounting to approximately $30 \%$ of its value, resulting from the changes in the eccentricity of the orbit and from precession. Currently, solar constant fluctuates during the year by $\pm 3.3 \%$ (with respect to the average distance of the Earth from the Sun). The value of the solar constant depends upon solar activity. According to Kondratev and Nikolskii (1970) solar constant in the years of the calm Sun is by more than $2 \%$ lower than during its moderate activity (for the Wolf numbers 80-100) and then drops again for the higher activity levels. R.Wetherald and S.Manabe (1975) stated that there exists a positive feedback between the greenhouse effect, caused by water vapour, and the temperature of the Earth's surface. This feedback causes that the increase of temperature resulting from the changes of the solar constant increases almost twofold. According to the authors mentioned (i.e. their circulation models) the warming of the troposphere corresponding to the increase of the solar constant by $2 \%$ is equivalent to doubling of the $\mathrm{CO}_{2}$ contents in the atmosphere.
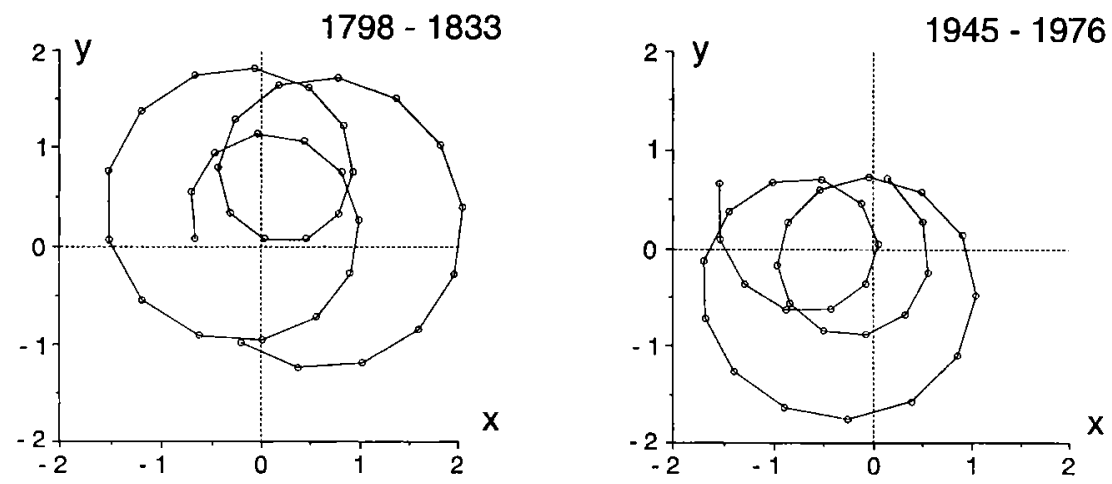

Fig. 4. Motion of the Sun around the center of the solar system during the weakest 13-year cycle 1811-1823, and the absolute maximum of the Wolf numbers (1957).

Two main minima of solar activity are known: the Maunder minimum of the years $1640-1710$ and the Dalton minimum of the years $1790-1830$, both characterized by the prolonged 11-year cycles, and two maxima with the centers in the years 1760 and 1940, characterized by the shortened 11-year cycles. Motion of the Sun around the center of mass of the solar system takes place along chaotic orbits during the minima, and along orderly orbits during the maxima (see Fig. 4). Full cycle takes 178.7 years. Such subsequent minimum of solar activity will occur in the middle of the next century (Charvatova, Strestik, 1996). A natural cooling of climate can therefore be expected in the 21 st century.

The progressing global warming may be caused by the increase of solar 
activity in two recent centuries - the increase of the solar constant. Activity of the Sun has been increasing in the years $1779-1993$ by 15.3/100 years on the average. It grew by almost $50 \%$ with respect to the average.

The deep minimum of solar activity (with the weakest 13-year cycle of the years 1811-1823) corresponds to the deep minimum of air temperature in Warsaw and in other localities in Europe. The maximum of the curve of air temperature changes occurs near to the absolute maximum of solar activity (1957). Besides this, the increasing trend of air temperature in Warsaw with the rate of $1^{\circ} \mathrm{C} / 100$ years in winter (Fig. 5) is explained by the resultant of 10 cycles: $3.5,5.5,8.3,12.9,15.2,18.0,38.3,66.7,113.1$ and 218.3 years (the increase by $0.84^{\circ} \mathrm{C} / 100$ years is explained by the sinusoid with the period of 218.3 years).

These cycles are natural, conditioned by the astronomical factors. Solar activity as well as the parameters of the solar system display similar cyclicity.

Besides this, volcanic eruptions were less and less frequent in 20th century. Currently, the influence of the fine volcanic dust, remaining in the atmosphere for many years, is no longer observed. Likewise, no forecasts of volcanic eruptions are being elaborated.

Each forecast requires adoption of definite assumptions. Scenarios of global warming are usually based upon the assumptions concerning solar constant, albedo, cloudiness, water vapur content, etc., the assumption of the doubling of $\mathrm{CO}_{2}$ content in the atmosphere, and the assumption that the latter will occur in the next century.

On the other hand, the forecasts of the natural changes of climate conform to the superposition of the identified periods of cyclicity are based on the assumption that the extremes of these cycles will be repeated - also in 21 st century.

It is obvious that the periods identified (in statistical sense) on the basis of measurement series are averaged over the whole period of approximation and are characterized by an "autodispersion". Thus, in some parts of the measurement series they are shorter, and in some other - longer. They also differ as to their amplitude, and may even altogether disappear. One can find evidence for this by applying the very same method of "regression sinusoids", which was used to identify the cycles (by dividing the measurement series into parts), or by applying the wavelet theory (Morlet, 1983). Even the 11-year cycle of solar activity fluctuates as to its length in the period 1700-1993 between 9 and 13 years. During the secular minima (of Maunder and Dalton) the 11-year cycle is prolonged and features low maxima. It is usually so that the shorter cycles of solar activity and air temperature are modulated by the longest cycles (Boryczka, 1994).

The so called autodispersion of the cycle lengths is also demonstrated by the very spectral bands which are quite wide in the prolonged length part (vast maxima with amplitude increments close to zero). The change of the longest periods (100 and 200 years) by $10 \%$ does not affect in a significant manner the forecasted values of temperatures in the next century. 
Side by side with this, there is also a dispersion of the cycle length, resulting from the variety of measurement series (differences of random samples).

The assumption of future repetitiveness of the cycles (at least in the 21st century) is justified by their repetitions in the past centuries.

The justification for the longest cycles - the ones of approximately 100 and 200 years - is constituted by their presence in the spectra of astronomical, geological and sedimentological variables. They are synchronous with the analogical cycles of solar activity, of solar constant, and the dust veil index in the atmosphere (DVI).

The 100- and 200-year cycles appear as the shortest periods of palaeotemperature: $78,180,400$ and 2400 years, determined on the basis of the ratio of the oxygen isotopes ${ }_{18} \mathrm{O} /{ }^{16} \mathrm{O}$ in the sediment cores (Johansen et al., 1970).

Further, the two similar cycles are observed in the time sequences of organic substance deposited in the sediments of Polish lakes:

$\begin{array}{lllll}\text { Wikaryjskie Lake } & & 200 & 300 & 2350 \text { years } \\ \text { Gościąż Lake } & 110 & 180 & 370 & 2310 \text { years } \\ \text { Święte Lake } & 120 & 190 & 370 & 2450 \text { years }\end{array}$

These are the shortest periods determined on the basis of the data from the approximation interval of 10,000 years. They are repeated there many times over.

The natural global fluctuations of climate (periods of warming and cooling) have been appearing since thousands of years and will still be there in the 21st century. The climate of the future century will be shaped by the changes in solar activity and volcanic eruptions (solar constant). On the top of natural variability of climate $\left(T_{0}\right)$ the anthropogenic variability $(\Delta T)$ will be superposed, caused by the greenhouse effect. These two components: $T=T_{0}+\Delta T$, have to be accounted for in the forecasts of climate for the next century. The natural global cooling and warming of climate cannot be neglected.

\section{REFERENCES}

B ory czka J., Wicik B., 1983, Holoceńskie cykle klimatu w środkowej Polsce na podstawie statystycznej analizy osadów jeziornych (Holocene cycles of climate in central Poland on the basis of statistical analysis of lake sediments; in Polish), Przegl. Geogr., XXVIII, 3-4.

B oryczk a J., Wi ęckowski K., Wicik B., 1989, Holocene climate changes in the light of statistical analysis of laminated sediments from the Gościęz Lake, Zeszyty Naukowe Politechniki Ślaskiej, Matematyka-Fizyka, issue 57, Geochronometria, 5 .

B or y c z k a J., W i c ik B., 1994, Record of holocene climatic cycles in lake sediments in Central Poland, Miscellanea Geographica. 
B ory c zk a J., 1984, Model deterministyczno-stochastyczny wielookresowych zmian klimatu (The Deterministic-Stochastic Model of Climate Changes; in Polish), Wyd. UW, Warszawa.

B o r y c z a J., 1993, Naturalne $i$ antropogeniczne zmiany klimatu Ziemi $w$ XVII-XXI wieku (Natural and Anthropogenic Changes of the Earth's Climate in 17th-21st Centuries; in Polish). Wyd. WG i SR, Warszawa.

Charvatova I., Strestik J., 1996, Udział długofalowych naturalnych zmian w obecnym ociepleniu globalnym, (The contribution of the long-term natural climate changes in the present global warming; in Polish), in: Proc. of International Conference: "Globalne ocieplenie a współczesne zmiany klimatyczne w Polsce" ("Global warming and the contemporary changes of climate in Poland"), Szczecin, May 31st-June 1st, 1993.

Flohn H., 1985, Climatic prospects in the case of an extended $\mathrm{CO}_{2}$-induced warming, Meteor. Zeit., H.1.

Joh ansen S.J., Dans gard W., Claus en H.B., Longway C.C., 1970, Climatic oscillations 1200-2000 AD, Nature, 227.

Kond ratev K.Ya., Nikolski G.A., 1970, Solar radiation and solar activity, Quarterly Journal of Royal Meteorological Society, 96.

Kożuchowski K., Boryczka J., 1997, Cykliczne wahania i trendy zmian poziomu morza w Świnoujściu (1811-1990) (Cyclical fluctuations and trends of changes in the sea level in Swinoujście (1811-1990), in Polish), Przegl. Geofiz., XLII, issue 1 .

L o ck w o o d J.G., 1979, Causes of Climate, London.

Milankovich M., 1938, Matematicheskaia klimatologiya i astronomicheskaia teoriya kolebanii klimata (Mathemtical Climatology and Astronomical Theory of Climate Oscillations, in Russian). ONTU, Moskva.

Morlet J., 1983, Sampling Theory and Wave Propagation, NATO ASI Series, F.I Springer.

Oeschger H., Si egenthaler U., 1987, Biosphere $\mathrm{CO}_{2}$ emissions during the past 200 years reconstructed by deconvolution of ice cover data, Tellus, $39 \mathrm{~B}$.

Wetherald R.T., Man abe S., 1975, The effect of changing the solar constant on the climate of a general circulation model, J. Atmospheric Sciences, 32.

WMO, 1990, The atmosphere of the planet Earth, Report No. 735. 